which has never been since surpassed. Dr. Schonland expressed disappointment that the membership in recent years has been but a little more than a thousand, for South Africa has expanded enormously since 1906 and with this expansion the need for, and potential value of, such a body as the Association. The general aims of the Association have not changed at all with the passing of years: "We exist," he said, "primarily to create and foster a scientific fraternity in South Africa, not to publish original work. We exist to provide a common meeting-ground for South African scientists and a forum for general discussion of the problems of this country from the scientific angle." He defended the use of Afrikaans by those who preferred it, for "we were intended by our founders to be parochial, and we should pride ourselves on being parochial. I would suggest that if we try to be anything else we will have mistaken our real aim".

Having thus firmly and, most people would agree, wisely placed the Association in its proper perspective, Dr. Schonland went on to make some concrete suggestions. The South African Journal of Science should have a series of semi-popular articles reviewing and surveying the new ideas of science and so bridge the gap between those who teach and do advanced research work and those who pay for it. This, he thought, is the proper function of the Journal, and it is but one aspect of the Association's duty, as representative of all sections of scientific opinion in South Africa, "to take a stronger, a more continuing and a more active interest in all scientific developments, national and university, in South Africa and to study carefully what is being done in other countries".

Besides his plea that the Association needs to form a standing committee to watch over scientific education in schools, Dr. Schonland suggested that the Association might consider taking a part in the formation of a body on the lines of the British Parliamentary and Scientific Committee and also help in the creation of better facilities for advanced. research in South Africa. On this last-named point, he cited the instances of the National University in Canberra and the Institute for Advanced Studies in Dublin, but he made the interesting suggestion that a more acceptable solution might be the creation of a number of specialized institutes for advanced study, attached to and forming part of those universities which for one reason or another are best suited for them.

\section{BASIS OF TECHNICAL EDUCATION}

CENERAL education to-day should be planned $\checkmark$ so as to enable the ordinary citizen to adapt himself to the needs of technological society and to understand what is happening and what is required of him. This was the theme of an international conference convened by the United Nations Educational, Cultural and Scientific Organization at Unesco House in June 1950*.

Broadly, the Conference found that organized social foresight is essential to enable the educational system of a country to prepare children for the type of life and work they are likely to encounter, and that a substantial development of technical education

* Education in a Technological Society : a Preliminary Inter national Survey of the Nature and Efficacy of Technical Education (Tensions and Technology Series.) Pp. 76. (Paris: Unesco; London :
H.M.S.O., 1952.) 200 francs ; 48.; 75 cents. is required at all levels : at present it is wholly inadequate for future needs, while the practical content of general education is also inadequate for the needs of future citizens of a technological society. The cultural content of technical education is also generally inadequate; technical education requires special consideration, and training for adaptability is an outstanding requirement in an age of ultra-rapid technological change. The education of women and girls also demands particular attention in view of their dual role as workers and home-makers, and improved administrative arrangements are essential if education is to fulfil its true function in such a society.

The report does not suggest that all these propositions apply equally to every country, though the Conference considered that, so far as its knowledge extended, they are generally valid for the world as a whole. The stress is laid on the need for adapting technology to man, not man to technology. The questions formulated in this report-and which merit attention in current discussions on the expansion of both technical and technological education in Great Britain-are raised in the belief that mastery of the machine by man is not an end in itself : it is a means to the development of man and of the whole society.

The distinction between technician and technologist is not always kept clear in this report, particularly in the chapter on the content of technical education. Nevertheless, the report directs attention to some fundamental issues which no sound policy for either type of education can disregard. In both fields it must be recognized that we are concerned not simply with the efficiency of production, but also with the fundamental attitude which the men and women of to-morrow will adopt in facing the problems of a technological society. Both, too, in seeking to foster flexibility, must recognize that flexibility is determined not only by education and training but also by social, economic and technical conditions; and the administrative measures required to ensure that education becomes more adapted to the needs of a changing technological society are themselves likely to be most effective when they are informal and varied rather than concentrated and uniform. The administrator, no less than the teacher and student, has need of frequent opportunities of contact with the industrial world, and requires experience of the difficulties and problems created by technological development in society; just as the teacher and student should keep abreast of developments in research and of practical applications in industry.

\section{GENETICAL IMPLICATIONS OF THE STRUCTURE OF DEOXYRIBONUCLEIC ACID}

\author{
By J. D. WATSON and F. H. C. CRICK
}

Medical Research Council Unit for the Study of the Molecular Structure of Biological Systems, Cavendish Laboratory, Cambridge

$T$ HE importance of deoxyribonucleic acid (DNA) within living cells is undisputed. It is found in all dividing cells, largely if not entirely in the nucleus, where it is an essential constituent of the chromosomes. Many lines of evidence indicate that it is the carrier of a part of (if not all) the genetic specificity of the chromosomes and thus of the gene itself. 